УДК 636.52/58:082

(C) 2014

\author{
Катеринич О. О., кандидат сільськогосподарських наук \\ Інститут тваринництва НААН
}

\title{
АНАЛІЗ ПАРАМЕТРІВ ФОРМУВАННЯ ЖИВОЇ МАСИ У ІНДИКІВ РІЗНИХ ГЕНОТИПІВ
}

\section{Рецензент - доктор сільскьгосподарських наук, професор Н. П. Пономаренко}

\begin{abstract}
Проведено щзотижневу оичінку живої маси ремонтного молодняку індиків вихідних ліній та гібридів, отриманих з їх використанням. Визначено параметри росту живої маси - інтенсивність формування $(\Delta t)$, індекс рівномірності (Ip) та напруги (IH). Встановлено статеві й генетичні відмінності за характером формування живої маси між батьківськими лініями індиків кросу «Харківський». Установлено значний рівень інформативності індексу напруги росту $в$ разі прогнозування живої маси індиків у 16-тижневому вічі $(r=0,72 ;-0,60)$.
\end{abstract}

Ключові слова: індики, жива маса, індекси формування, корелячія.

Постановка проблеми. Індиківництво є однією 3 перспективних галузей м'ясного птахівництва. Висока швидкість росту й якість м'яса визначили їх значну нішу у загальному балансі виробництва пташиного м'яса (близько 22-26\%) [9]. Сучасний ринок виробництва країни зосереджено на використання генетичних ресурсів: вітчизняної (крос «Харківський») та закордонної («But-8»; «Big-6»). Вітчизняний крос «Харківський» відноситься до середнього типу. Індики батьківської лінії «5» мають у 30-тижневому віці живу масу 8,2 кг (самки) і 13,6 кг (самці), несучість - 79 яєць за 21 тиждень продуктивного періоду, заплідненість яєць 90,8 \%, вивід молодняку 81,8 \%, виводимість яєць 90,0 \%; збереженість індичат 96,9 \%, вихід індичат на самку 58,4 голів. Рівень господарськи корисних ознак материнської лінії «6» становить: жива маса - 7,5 кг (самки) і 12,4 кг (самці), несучість - 84,0-93,6 яєць за 21 тиждень продуктивного періоду, заплідненість яєць 91,1-93,8 \%, вивід молодняку 83,2-85,8 \%, виводимість яєць 91,3-91,5\%, збереженість індичат 97,6 \%, вихід індичат на самку 63,7-72,6 голів [3].

Аналіз основних досліджень і публікацій, у яких започатковано розв'язання проблеми. Системний аналіз індивідуального розвитку особин - один із головних напрямів, який передбачає контроль за реалізацією генетичної інформації у сукупності з паратиповими факторами на протязі онтогенезу [1; 7]. Одним із важливих показників росту, розвитку та продуктивності тварин і птиці є жива маса, яка залежить від індиві- дуальних особливостей, спадкових властивостей, статі, віку, рівня годівлі, умов утримання та інших факторів. Для розвитку особин застосовують щомісячний контроль живої маси впродовж вирощування молодняку тварин і птиці [4; 7]. 3 використанням отриманих даних визначають закономірності реалізації генетичного потенціалу росту тварин і птиці в онтогенезі. Для цього використовують цілий ряд показників, які характеризують прирости живої маси (середньодобовий і відносний) та індекси іiі формування (рівномірності, напруги, інтенсивності росту) $[6 ; 8 ; 10]$.

3 урахуванням вищезазначеного, метою роботи було визначення параметрів росту вихідних ліній індиків та гібридів, отриманих за їх схрещування.

Завдання дослідження. Для досягнення мети було розраховано параметри росту живої маси індиків (інтенсивність формування, $\Delta \mathrm{t}$; індекс рівномірності, Ip; індекс напруги, IH). Із використанням отриманих показників проведено порівняльний аналіз батьківських форм кросу «Харківський». Проведено розрахунки кореляційного зв'язку між параметрами формування та живою масою індиків у 16тижневому віці.

Матеріали і методи досліджень. Дослідження проведено у відділі птахівництва Інституту тваринництва НААН. Використано дані вирощування ремонтного молодняку вихідних ліній індиків 5 (n=200 голів) і 6 (n=200 голів) кросу «Харківський» за розведення у собі та за схрещування 3 індиками кросу «Big 6»- 7 х 5 (n=87 голів) і 7 х 6 (n=155 голів).

Живу масу ремонтного молодняку у кожній групі визначали до 16-тижневого віку, щотижнево. Птиця утримувалася на підлозі згідно 3 нормами ВНТП [2].

3 урахуванням величини живої маси, за окремі вікові періоди (4, 8, 16 тижнів життя) розраховано наступні показники: інтенсивність формування $\Delta \mathrm{t}[11]$; індекс рівномірності росту Ip; індекс напруги росту IH [6].

Результати досліджень. Результати вирощування ремонтного молодняку індиків різних генотипів наведено в таблиці 1. 
СІЛЬСЬКЕ ГОСПОДАРСТВО. ТВАРИННИЦТВО

1. Жива маса лінійного та гібридного ремонтного молодняку у 16 тижнів жсття

\begin{tabular}{|c|c|c|c|c|c|c|c|c|}
\hline Вік, & \multicolumn{2}{|c|}{5} & \multicolumn{2}{c|}{$7 \times 5$} & \multicolumn{2}{c|}{6} & \multicolumn{2}{c|}{$7 \times 6$} \\
\cline { 2 - 9 } тижні & $\mathrm{M}$ & $\mathrm{m}$ & $\mathrm{M}$ & $\mathrm{m}$ & $\mathrm{M}$ & $\mathrm{m}$ & $\mathrm{M}$ & $\mathrm{m}$ \\
\hline Самці & 7841,2 & 78,32 & 7630,6 б & 131,30 & $7630,0 \mathrm{a}$ & 73,43 & $7804,1 \mathrm{\text { }}$ & 113,84 \\
\hline Самки & 5805,0 & 56,02 & 5766,7 & 104,3 & $5631,7 \mathrm{a}$ & 44,82 & 6434,5 в & 138,99 \\
\hline
\end{tabular}

Примітка. Статистична значимість різниці між лініями 5 та 6: a - p $\leq 0,001$; статистична значимість різниці між лінією 5 і гібридом 7 х 5: б - p $\leq 0,001$; статистична значимість різниці між лінією 6 і гібридом 7 х 6: в $\mathrm{p} \leq 0,001$.

Жива маса самців та самок батьківської лінії 5 вірогідно перевищує відповідні показники лінії 6 - 7841,2 і 5805,0 (г) і 7630,0 і 5631,7 (г) відповідно. Прилиття крові до батьківської лінії $(7 \times 5)$ призвело до вірогідного зниження $(\mathrm{p} \leq 0,001)$ живої маси самців (до 7630,6 г) та самок $(5766,7$ г). Для материнської лінії, навпаки, встановлено вірогідне $(\mathrm{p} \leq 0,001)$ зростання живої маси у гібридів: до 7804,1 та 6434,5 г, для самок і самців відповідно.

3 використанням показників живої маси розраховано показник інтенсивності формування за 4-, 8- та 16-тижневі періоди вирощування (табл. 2).

\section{2. Інтенсивність формування (Дt) живої маси у процесі вирощування ремонтного молодняку індиків різних генотипів}

\begin{tabular}{|c|c|c|c|c|c|c|}
\hline \multirow{2}{*}{$\begin{array}{c}\text { Лінії, } \\
\text { гібриди, } \\
\text { коди }\end{array}$} & \multicolumn{3}{|c|}{ Самці } & \multicolumn{3}{c|}{ Самки } \\
\cline { 2 - 7 } & 4 & 8 & 16 & 4 & 8 & 16 \\
\hline 5 & 25,82 & 7,83 & 38,57 & 21,32 & 9,84 & 40,23 \\
\hline 6 & 19,84 & 7,73 & 39,93 & 34,34 & 11,60 & 38,01 \\
\hline $7 \times 5$ & 24,13 & 8,68 & 39,82 & 26,27 & 15,57 & 38,52 \\
\hline $7 \times 6$ & 21,84 & 5,83 & 38,61 & 26,36 & 12,22 & 33,20 \\
\hline
\end{tabular}

На відміну від курей [5], мінливість формування живої маси у індиків протягом онтогенезу має іншу закономірність: розвиток індиків супроводжується зниженням величини інтенсивності формування живої маси за 8 тижнів життя у порівнянні з 4-тижневим періодом. Величина $\Delta \mathrm{t}$ за 16 тижнів вирощування вказує на значне зростання інтенсивності впродовж 8-16-тижневого періоду.

Водночас прилиття крові до батьківської лінії призводить до певного зниження інтенсивності формування за 4 тижні та зростання за 8 і 16 тижнів життя у самців. Для самок встановлено зростання показника $\Delta \mathrm{t}$ за перші 4 та 8 тижнів життя і зниження за загальний період (16 тижнів).

За результатами аналізу поєднання, отриманого від материнської лінії, встановлено інші закономірності: для самців (7х6) відмічено зростання інтенсивності формування за 4 тижні життя із подальшим його зниженням за 8- та 16-тижне- вий періоди. Для самок зростання $\Delta \mathrm{t}$ відбувається лише за 8-тижневий період.

Кореляційний зв'язок між інтенсивністю формування за 4 та 8 тижнів життя й живою масою у 16-тижневому віці для самців встановлено на середньому рівні $(\mathrm{r}=0,49 ;-0,56)$. Для самок коефіцієнт кореляції характеризує більш низький зв'язок $(\mathrm{r}=-0,29 ;-0,23) .3$ урахуванням розрахованого зв'язку відмічено середній рівень інформативності показника $\Delta \mathrm{t}$ для прогнозування живої маси. Проте даний висновок не $\epsilon$ кінцевим $\mathrm{i}$ потребує глибших досліджень.

Наступний аналіз було спрямовано на визначення індексу рівномірності росту (Iр) живої маси (табл. 3).

Згідно з отриманими даними, для самців і самок індиків різних генотипів установлено суттеве зростання рівномірності розвитку живої маси 3 4-го по 8-й тижні життя, - далі, з 8-го по 16-й тиждень життя відбувається зниження величини Ір.

Рівномірність розвитку живої маси у самців батьківської лінії (5) нижча, порівняно $з$ лінією 6 за 4- і 8-тижневий періоди. Для самок за відповідний період більша рівномірність відмічена у лінії 5. Величина Iр за загальний період досліджень відмічена, навпаки, для самців 5-ої та самок 6-ої ліній. Прилиття крові призводить до протилежних наслідків, відповідно, для батьківської й материнської ліній. Разом із тим загальне зростання рівномірності у самців і самок встановлено для поєднання 7х6 - 173,00 та 165,06 відповідно.

\section{3. Індекс рівномірності Ір росту живої маси за вирощування ремонтного молодняку індиків різних генотипів}

\begin{tabular}{|c|c|c|c|c|c|c|}
\hline $\begin{array}{c}\text { Лінії, } \\
\text { гібриди, } \\
\text { коди }\end{array}$ & 4 & 8 & 16 & 4 & 8 & 16 \\
\hline 5 & 75,50 & 429,05 & 174,15 & 76,69 & 275,82 & 123,24 \\
\hline 6 & 97,74 & 430,34 & 167,71 & 48,62 & 227,22 & 126,15 \\
\hline $7 \times 5$ & 79,55 & 386,54 & 164,31 & 64,31 & 174,19 & 127,80 \\
\hline $7 \times 6$ & 88,04 & 557,46 & 173,00 & 62,95 & 222,34 & 165,06 \\
\hline
\end{tabular}




\section{СІЛЬСЬКЕ ГОСПОДАРСТВО. ТВАРИННИЦТВО}

Кореляційний зв'язок між індексом рівномірності росту живої маси за 4 та 8 тижнів життя й живою масою у 16-тижневому віці при подібності за величиною має протилежний характер у порівнянні $з$ показником $\Delta \mathrm{t}$. Максимальний рівень зв'язку встановлено для самців (r = -0,47; 0,56). Отримані дані підтверджують середній рівень інформативності показника Iр для прогнозування живої маси.

Загальна тенденція мінливості індексу напруги росту живої маси в онтогенезі спрямована на його максимальне зростання впродовж перших 4-х тижнів життя. Подальші 4 тижні характеризуються значним зниженням величини IН. Загальні величини IH за 16 тижнів вирощування індиків майже вдвічі нижчі порівняно з величиною за перші 4 (табл. 4).

\section{4. Індекс напруги росту (IН) жсивої маси за вирощування ремонтного молодняку індиків різних генотипів}

\begin{tabular}{|c|c|c|c|c|c|c|}
\hline $\begin{array}{c}\text { Лінії, } \\
\text { гібриди, } \\
\text { коди }\end{array}$ & \multicolumn{3}{|c|}{ Самці } & \multicolumn{3}{c|}{ Самки } \\
\cline { 2 - 7 } & 4 & 8 & 16 & 4 & 8 & 16 \\
\hline 5 & 114,63 & 17,39 & 42,80 & 87,11 & 20,09 & 41,08 \\
\hline 7 & 91,81 & 17,88 & 45,05 & 147,56 & 24,93 & 40,84 \\
\hline $7 \times 5$ & 102,59 & 18,46 & 42,33 & 103,20 & 30,58 & 37,83 \\
\hline $7 \times 6$ & 100,86 & 13,45 & 44,57 & 105,05 & 24,34 & 33,08 \\
\hline
\end{tabular}

За результатами порівняльного аналізу, більший індекс напруги росту встановлено для самців лінії $5(114,63)$ лише за 4-тижневий період. Подібна закономірність із протилежним характером відмічена для самок, із більшим значенням для лінії $6(147,56)$.

Прилиття крові (як у випадку 3 вищезазначеними показниками) має протилежні наслідки за

\section{БІБЛІОГРАФІЯ}

1. Боголюбский С. И. Селекция сельскохозяйственной птицы / С. И. Боголюбский. - М. : Агропромиздат, 1991. - 290 с.

2. Відомчі норми технологічного проектування: Підприємства птахівництва: ВНТП-АПК-04.05. Мінагрополітики України. - К., 2005. - 90 с.

3. Гадючко O. T. Сучасний генофонд вітчизняного і зарубіжного походження та перспективи його використання в Україні / О. Т. Гадючко, О. О. Катеринич, В. П. Коваленко // Птахівництво : міжвід. темат. наук. зб. - ІП НААН. - Х., 2008. - Вип. 62. - С. 59-82.

4. Іванов В. О. Особливості росту та адаптації курей у ранньому онтогенезі / В. О. Іванов, M. В. Архангельська // Таврійський науковий вісник. - Херсон, 1999. - Вип. 11. - С. 107-111. перші 8 тижнів вирощування птиці. Для самців поєднання (7x5) встановлено зниження величини IH упродовж перших 4-х тижнів, при несуттєвому зростанні за 8 тижнів. Протилежну картину відмічено для поєднання 7х6. Для самок різних генотипів також відмічено різний характер мінливості показника IH. Водночас перевага за загальними величинами показників напруги росту встановлена для гібридних самців порівняно 3 самками. Максимальний із-поміж вищенаведених рівень кореляції встановлено між показником IH у самців за 4 та 8 тижнів життя і живої маси у 16-тижневому віці $(\mathrm{r}=0,72 ;-0,60)$.

Для самок цей показник значно нижчий ( $\mathrm{r}=-0,35 ;-0,13)$. Отримані дані вказують на перевагу за рівнем інформативності показника $\mathrm{IH}$ для прогнозування живої маси самців індиків.

Таким чином, визначено параметри формування живої маси в індиків різних генотипів та напрями їх мінливості в онтогенезі. Разом із цим встановлено значний рівень інформативності індексу напруги росту в прогнозуванні живої маси індиків у 16-тижневому віці. Розраховані показники росту живої маси доцільно використовувати в селекційній роботі для контролю за розвитком особин та груп (ліній, популяцій) птиці й прогнозування їх кінцевого значення.

Висновки: 1. Встановлено статеві та генетичні відмінності за характером формування живої маси між батьківськими лініями індиків кросу «Харківський».

2. Встановлено рівень зв'язку між показниками формування живої маси за 4 та 8 тижнів життя 3 ії величиною у 16-тижневому віці. Максимальний рівень інформативності встановлено для індексу напруги росту живої маси у самців $(\mathrm{r}=0,72 ;-0,60)$.

5. Катеринич О. О. Порівняльний аналіз формування інформаційної структури ознаки «жива маса» у курей різного напряму продуктивності носіїв гену «Dw-/dw-» / О. О. Катеринич, С. В. Руда // Сучасне птахівництво. - 2013. - № 1. - С. 10-12.

6. Коваленко В. П. Сучасні методи оцінки і прогнозування закономірностей онтогенезу тварин і птиці / В. П. Коваленко, Т. І. Нежлукченко, С. Я. Плоткін // Вісник аграрної науки, 2008. № 2. - C. 40-45.

7. Недашківський В. М. Лінійний ріст курчатбройлерів за різних рівнів годівлі / В. М. Недашківський, Н. М. Слободянюк, В. М. Кондратюк // Сучасне птахівництво. - 2008. - №11-12 (72-73). - C. 29-32. 
8. Патрєва Л. С. Розробка та використання удосконалених методів селекції птиці м'ясного типу: дис. ... доктора с.-г. наук: 06.02.01 / Патрєва Людмила Семенівна. - Херсон, 2007. - 386 с.

9. Петров $\epsilon$. Про стан галузі птахівництва України та його майбутнє / $Є$. Петров // Ефективне птахівництво. - 2010. - №3(63). - С. 10-12.

10. Полякова В. О. Використання параметрів інтенсивності росту ремонтного молодняку свиней для прогнозування живої маси при відгодівлі / В. О. Полякова // Таврійський науковий вісник. - Херсон, 1999. - Вип. 10. - Ч. 1. - С. 194-196.

11. Свечин Ю. К. Прогнозирование продуктивности животных в раннем возрасте / Ю. К. Свечин // Вестник сельскохозяйственной науки. - М., 1985. - №4. - С. 103-105. 